\title{
Fatty acid composition of muscle and adipose tissue of indigenous Polish geese breeds
}

\author{
Andrzej Okruszek
}

Department of Animal Food Technology, Wrocław University of Economics, Wrocław, Poland

\begin{abstract}
The aim of the study was to compare the fatty acid profile in lipids of breast and leg muscles as well as in adipose tissue of 24-week-old Rypińska $(n=20)$ and Garbonosa $(n=20)$ geese from unique indigenous conservation flocks, maintained using the in situ method at the Research Station of Waterfowl Genetic Resources in Dworzyska, belonging to the National Research Institute of Animal Production in Krakow, Poland. The geese from both flocks were fed ad libitum by the same complete feed: until the 6 th week of age which contained: $19.0 \%$ crude protein, $4.0 \%$ crude fat, $3.5 \%$ fibre and up to $12.0 \mathrm{MJ}$ metabolisable energy, and later from the 7 th to the 24 th week of age up to $17.0 \%$ crude protein, $3.0 \%$ crude fat, $5.0 \%$ crude fibre and $11.3 \mathrm{MJ}$ metabolisable energy per $1.0 \mathrm{~kg}$ of feed.

On the basis of carried experiment it was stated, that the lipids of breast muscles of Garbonosa geese contained less saturated fatty acids (SFAs) (without C 14:0) and more the C $20: 4 n-6$ (6.96\% vs. $6.36 \%)$, C $20: 5 n-3$ - eicosapentaenoic acid (EPA) (1.16\% vs. $1.10 \%)$, C 22:4 $n-6$ (0.69\% vs. $0.64 \%$ ) and C 22:6n-3 - docosahexaenoic acid (DHA) (0.44\% vs. $0.38 \%)$ than in Rypińska, whereas in lipids of leg muscles of Rypińska there was a higher level of C $14: 0(0.53 \%$ vs. $0.50 \%), C$ 18:1 cis-9 (37.64\% vs. $37.33 \%), C 18: 2 n-6(16.26 \%$ vs. $15.97 \%)$ and a C $18: 3 n-3(0.83 \%$ vs. $0.80 \%)$ and lower of C $20: 4 n-6$ (7.63\% vs. $7.79 \%)$ as well as $C 20: 5 n-3$ - EPA (1.49\% vs $1.51 \%)$ compared to the Garbonosa geese flock. The higher concentration of $C$ 14:0, C 16:0, C 16:1 trans-9, a C 18:3 $n-3$, and lower concentration $(P \leq 0.01)$ of long-chain polyunsaturated fatty acids (PUFAs) in both flocks was found out in lipids of breast than leg muscles. The adipose tissue of Rypińska was characterised by higher $(P \leq 0.01)$ content of C $14: 0$ (by $0.12 \%), C 16: 0$ (by $1.75 \%$ ), C $16: 1$ cis-9 (by $0.78 \%$ ) and lower $(P \leq 0.01$ ) content of C $18: 1$ cis -9 (by $2.8 \%$ ), C 18:2n-6 (by 1.48 \%) and C 20:4 n-6 (by 0.19\%) compared to Garbonosa geese.
\end{abstract}

Keywords: goose, fatty acids profile, breast and leg muscles, adipose tissue

\section{Introduction}

There are many different geese breeds and, as in other countries, in Poland is carried out a breeding program for the preservation of geese genetic resources. These conservative flocks can be used in the development of new breeding and experimental strains and synthetic lines as well as in the search for heterosis effects in commercial sets (Książkiewicz 2003). The world's genetic resources conservation programme currently includes 14 Polish geese populations (varieties) maintained in Poland: Biłgorajska, Zatorska, Garbonosa, Kartuska, 
Kielecka, Lubelska, Podkarpacka, Pomorska, Rypińska, Suwalska, Słowacka, Romańska, Kubańska and Landes.

In recent years an increasing number of consumers have concerns about the quality of poultry meat. According to Gumułka et al. (2006) products obtained from geese are characterised by specific features compared to galliformes birds. However, many consumers are afraid of health problems because of a high content of fat in meat and adipose tissue in the carcass. Improving food quality and nutritional value is an important tool used by modern nutritionist to help, not only to feed an ever-increasing human population, but also to enhance health and longevity (Qi et al. 2010). It's well-known that fatty acids of lipids play important metabolic, structural and functional roles in physiology (Mennicken et al. 2005). The goal is to produce meat which meets the dietary recommendations for a reduced intake of fat and cholesterol in the human diet and an optimal ratio of saturated (SFAs), monounsaturated (MUFAs) and polyunsaturated (PUFAs) fatty acids (EFSA 2010). Among the PUFAs, great attention is paid to $n-3$ fatty acids, especially long-chain $n-3$ (EPA and DHA), which have several benefits for human health, and conjugated linoleic acid which have exhibited anticarcinogenic and antiatherogenic properties in animal studies and favourably modulate immune function in humans (McAfee et al. 2010).

Geese fat is regarded to be relatively safe for consumers, as it contains a high proportion of monounsaturated oleic, linoleic, linolenic and arachidonic acids (about 24, 20, 0.4 and $0.05 \%$, respectively), all being products of enzymatic desaturation of stearic acid (C 18:0). Especially geese kept on grassland (pastures) and fed diverse feeds, consume more PUFAs than other species of poultry, maintained under a closed system and fed standard feeds low in linoleic acid and PUFAs, while rich in SFAs. In consequence, the meat and fat tissue of gallinaceous poultry of meat type is observed to contain less $n-3$ acids (Rosiński 2000). Goose fat, containing a higher proportion of PUFAs with at least two unsaturated sites and rich in vitamins and deficient minerals, can be treated as a »functional food «. The increased consumption of unsaturated $n-3$ fatty acids (e.g. a-linolenic) reduces the risk of stenocardia in humans. (Wężyk et al. 2003).

There are no adequate data on the fatty acid profile of lipids from muscles and adipose tissue of geese, especially from conservative flocks. It seems reasonable to analyse these profiles. The aim of the present paper was to estimate and compare the fatty acid content in lipids of breast and leg muscles and adipose tissue of two indigenous Polish geese breeds Rypińska and Garbonosa.

\section{Material and methods}

\section{Animals, diets and experimental procedure}

The experiment involved 24-week-old geese from two native conservative flocks ( $n=20$ birds for each flock): Rypińska and Garbonosa (Table 1), registered in the FAO World Watch List (FAO 2000) and conserved using the in situ method as a »gene bank« at the Research Station of Waterfowl Genetic Resources in Dworzyska, belonging to the National Research Institute of Animal Production in Kraków, Poland as separate closed populations.

During the testing period geese were reared up to the 6th week of age in a brooder house of controlled air temperature, and afterwards until the 24th week of age they were kept 
on yards of restricted area (stocking density $\approx 0.75-0.85$ per $1 \mathrm{~m}^{2}$ ), covered with straw and partially roofed (each flock of geese was reared separately). The geese from all flocks were fed ad libitum on the same complete feeds - up to the 6th week of age all-mash KBR-Z/1 and later from the 7th up to the 24th week of age all-mash KBR-Z/2 (Table 2).

Table 1

Characteristics of investigated goose flocks (Mazanowski 2002)

\begin{tabular}{|c|c|c|c|c|}
\hline Flock & $\mathrm{N}_{f}$ & $\mathrm{~N}_{\mathrm{m}}$ & $\mathrm{N}_{\mathrm{e}}$ & Short characteristics \\
\hline $\begin{array}{l}\text { Rypińska geese - old, } \\
\text { indigenous breed native } \\
\text { to northern Poland }\end{array}$ & 217 & 64 & 198 & $\begin{array}{l}\text { Mostly white plumage, sometimes piebald. Birds are known } \\
\text { for good health, resistance to unfavourable environmental } \\
\text { conditions, very good meatiness and dietary efficiency. } \\
\text { Ideally suited for the creation of hybrids. }\end{array}$ \\
\hline $\begin{array}{l}\text { Garbonosa geese - old, } \\
\text { indigenous breed native } \\
\text { to southern Poland }\end{array}$ & 231 & 83 & 244 & $\begin{array}{l}\text { Mostly white plumage, sometimes piebald. Known for good } \\
\text { health, resistance to unfavourable environmental } \\
\text { conditions, good meatiness, low fatness and very good } \\
\text { reproductive performance. Birds are characterised by good } \\
\text { feed efficiency and can be used to produce three- or four- } \\
\text { strain hybrids with increased meatiness. }\end{array}$ \\
\hline
\end{tabular}

$\mathrm{N}_{\mathrm{m}}$ : number of males, $\mathrm{N}_{\mathrm{f}}$ number of females, $\mathrm{N}_{\mathrm{e}}$ : effective size of population; $\mathrm{N}_{\mathrm{e}}=\left(4 \mathrm{~N}_{\mathrm{m}} \times \mathrm{N}_{\mathrm{f}}\right) / \mathrm{N}_{\mathrm{m}}+\mathrm{N}_{\mathrm{f}}$ (Falconer \& Mackay 1996) (1 February 2010)

Table 2

Chemical composition and fatty acid content of all-mashes, including calculated metabolisable energy content

\begin{tabular}{lcc}
\hline & KBR-Z/1 & All-mash \\
& & \\
\hline Chemical composition, \%/kg of all-mash & & \\
Crude protein & 19.00 & 17.00 \\
Crude fat & 4.00 & 3.00 \\
Ash & 5.50 & 6.00 \\
Crude fibre & 3.50 & 5.00 \\
Lysine & 1.05 & 0.820 \\
Methionine & 0.49 & 0.46 \\
Calcium & 0.85 & 0.86 \\
Total phosphorus & 0.70 & 0.80 \\
Vitamin A, IU/kg & 15000 & 14000 \\
Vitamin $\mathrm{B}_{3^{\prime}}$ IU/kg & 3500 & 2000 \\
Vitamin $\mathrm{mg} / \mathrm{kg}$ & 60 & 50 \\
Metabolisable energy, MJ/kg of all-mash* & 11.30 \\
Fatty acid, \% of a sum fatty acids & 12.00 & \\
C 16:0 & & 11.80 \\
C 16:1 cis-9 & 12.20 & 0.31 \\
C 18:0 & 0.37 & 4.95 \\
C 18:1 cis-9 & 5.60 & 32.20 \\
C 18:2 $n-6$ & 29.40 & 34.40 \\
C 18:3 $n-3$ & 37.60 & 4.26 \\
C 20:5 $n-3$ & 2.58 & 0.70 \\
C 22: 6 -3 3 & 0.62 & 0.62 \\
\hline
\end{tabular}

*The caloric value of all-mashes was calculated on the basis of percentage content of some analytic components of feed, expressed in MJ metabolisable energy per $1.0 \mathrm{~kg}$ of fed mixture, with a level of nitrogen adjusted in the following method Dz. U. Nr. 63, item No. 589 (Minister of Agriculture and Rural Development 2004): MJ/kg ME=0.1551×\% crude protein $+0.3431 \times \%$ crude fat $+0.1669 \times \%$ starch $+0.1301 \times \%$ total sugar content (expressed as sucrose). 
All birds were weighed at the 24th week of age using an electronic balance to an accuracy of $5 \mathrm{~g}$. Based on average live body weights $(\approx 4650 \mathrm{~g})$ of geese, 20 females from each flock were selected for investigations. Twelve hours before slaughter, birds were only allowed access to water. Birds were slaughtered in an experimental slaughterhouse, belonging to Research Station of Waterfowl Genetic Resources in Dworzyska according to the relevant regulations applied in the Polish poultry industry. After a $24 \mathrm{~h}$ chilling period $\left(2-4^{\circ} \mathrm{C}\right)$ the carcasses were jointed. Cutting out from the right side of the carcases leg (thigh and drumstick) and breast muscles with intramuscular fat and without skin and subcutaneous fat as well as adipose tissue were transported at $2-4^{\circ} \mathrm{C}$ to the Animal Food Technology Department University of Economics in Wrocław. The samples of muscles $(\approx 2.0 \times 2.0 \times 5.0 \mathrm{~cm})$ and adipose tissue $(\approx 8.0 \mathrm{~g})$ from analysed flocks of geese were stored at $-80^{\circ} \mathrm{C}$ until further chromatograph analysis.

\section{Fatty acid profile analysis}

Preliminary grinded meat tissues and adipose tissue were homogenised with a T 25 Ultra Turrax (IKA-Werke GmbH \& Co. KG, Staufen, Germany). Lipids extraction was carried out according to the procedure described by Folch et al. (1956). The fatty acids composition of meat and adipose tissue were determined by Capillary Gas Chromatography technique. For the determination of fatty acids composition the lipid samples were converted to their corresponding methyl esters by AOCS official method Ce 2-66 (AOCS 1997). The fatty acids methyl esthers (FAMEs) were quantified by gas chromatography method using a fused silica capillary column J\&W Scientific HP-88 series $-100 \mathrm{~m} \times 0.25 \mathrm{~mm} \times 0.20 \mu \mathrm{m}$ film thickness (Agilent Tech. Inc., St. Clara, CA, USA) and flame-ionization detector in Agilent Tech. 7890 A series gas chromatograph (Agilent Tech. Inc., St. Clara, CA, USA) at injection volume of $1.0 \mathrm{~mL}$ and split ratio $1 / 50$ respectively. Helium was used as the carrier gas at a head pressure of $2.0 \mathrm{~mL} / \mathrm{min}$ constant flow. Air, hydrogen and helium make-up gas flow rates by flameionization detector were: 450,40 and $30 \mathrm{~mL} / \mathrm{min}$., respectively. The detector and injector temperatures were chosen as $280^{\circ} \mathrm{C}$ and $250^{\circ} \mathrm{C}$, respectively. The initial column temperature of $120^{\circ} \mathrm{C}$ was held for $1 \mathrm{~min}$, increased to $175^{\circ} \mathrm{C}$ at $10^{\circ} \mathrm{C} / \mathrm{min}$ and held for $10 \mathrm{~min}$. Then, it was increased to $210^{\circ} \mathrm{C}$ at $5^{\circ} \mathrm{C} / \mathrm{min}$, held $5 \mathrm{~min}$, and finally increased to $230^{\circ} \mathrm{C}$ at a rate of $5^{\circ} \mathrm{C} /$ min, and maintained for 5 min. Quantification of muscles and adipose tissue lipids FAMEs was carried out using nonadecanoic acid (C 19:0) as an internal standard.

The peaks were identified by comparing the retention times with those of a mixture of external standard methyl esters (Supelco 37 FAME Mix C 4-C 24 Component, Sigma-Aldrich, St. Louis, MI, USA). The fatty acids were calculated as \% of a sum of fatty acids with the ChemStation Agilent Technologies program (Agilent Tech. Inc., St. Clara, CA, USA). Total lipid contents in muscles and abdominal fat were analysed and quantified according to Soxhlet procedure (AOAC 1990).

\section{Statistical analysis}

Statistical analyses (Statistica 9, StatSoft, Inc. Tulsa, OK, USA) included:

- calculation of the arithmetic means $(\overline{\mathrm{X}})$ and standard deviations (SD) of all the investigated parameters; 
- analysis of variance (ANOVA) on a one-factor design (with two levels) between breeds of geese' flock and particular type of muscles and adipose tissue within analysed flocks, according to the linear model:

$Y_{i j}=\mu+A_{j}+e_{i j}$

where $Y_{i j}$ is the value of trait, $\mu$ is the overall mean, $A_{j}$ is the effect of type of flock or particular type of muscles and adipose tissue within analysed flocks and $e_{i j}$ is the random observation error.

- determination of the significance of differences between means for the investigated parameters in analysed kinds of flocks as well as between particular type of muscles (breast and leg) and adipose tissue, within individual flocks were determined by Duncan's multiple range test. Differences were considered as significant at the level of 0.05 and 0.01 .

\section{Results}

\section{Effect of the geese breeds}

The fatty acids composition of leg muscles, breast muscles and abdominal adipose tissue of Garbonosa and Rypińska geese is summarised in Table 3. In spite of the same environmental conditions (i.e. feed, housing conditions and age), the concentration of fatty acids in the breast and leg muscles and abdominal adipose tissue differed between both goose breeds. Indicating an effect of the goose breeds on the fatty acids profile in muscles and adipose tissue was found. The lipids of breast muscles of Garbonosa contained significantly higher percentages of tetradecanoic - C 14:0 and cis-9-hexadecenoic - C 16:1 cis-9 acids as well as the polyunsaturated fatty acids, i.e.: cis-9,12-octadecadienoic - C 18:2 n-6, cis-5,8,11,14eicosatetraenoic - C 20:4 n-6, cis-4,7,10,13,16,19-docosahexaenoic (DHA) - C 22:6n-3 ( $P \leq 0.01)$ and less cis-9-octadecenoic - C 18:1 cis-9 $(P \leq 0.05)$ in comparison to the Rypińska. In the case of leg muscles higher content of $C 14: 0,(P \leq 0.01), C 18: 1$ cis-9 and trans-11-octadecaenoic C 18:1 trans-11 $(P \leq 0.05)$ were detected in the lipids of Rypińska than Garbonosa.

The adipose tissue of Rypińska was characterised by significantly higher content of saturated fatty acids, e.g.: $C 14: 0, C 16: 0$ as well as $C 16: 1$ cis-9 $(P \leq 0.01)$ and lower content of $C$ 18: 1 cis-9, $C 18: 2 n-6, C 20: 4 n-6(P \leq 0.01)$ as well as $C 18: 1$ trans-11 $(P \leq 0.05)$ fatty acids compared to Garbonosa. In adipose tissue lipids, for both analysed flocks of geese the longchain of polyunsaturated fatty acids (PUFAs), including C 20:5 n-3 - EPA and C 22:6n-3 - DHA was not observed (Table 3).

\section{Effect of the tissue-specific}

The differences in the fatty acids content of lipids, depending on the kind of muscles (breast and leg) within the studied flocks of geese were observed too. Higher concentrations' of $C$ 14:0, C 16:0, C 16:1 trans-9, a C 18:3 n-3 (cis-9,12,15-octadecatrienoic acid) and lower of longchain PUFA, e.g.: C 20:4 n-6, C 20:5 n-3 - EPA, C 22:4 n-6 and C 22:6n-3 - DHA ( $P \leq 0.01)$ in both flocks were detected in breast lipids compared to leg muscles $(P \leq 0.01)$.

In both investigated flocks of geese saturated and monounsaturated fatty acids were the predominant components both in muscles and adipose tissue lipids, whereas the concentration of polyunsaturated fatty acids was relatively lower. The lipids of the breast 
muscles and adipose tissue in Rypińska were characterised by lower UFAs content (by $1.06 \%$ breast muscles and $3.82 \%$ - adipose tissue, respectively) and PUFAs - except leg muscles (by $1.83 \%$ - breast muscles and $1.75 \%$ - adipose tissue, respectively) compared to Garbonosa. Moreover, lower contents of the UFAs, MUFAs, PUFAs and higher SFAs content in both flocks of geese were found out in lipids of breast compared to leg muscles' lipids (Table 3).

The $\Sigma$ UFA/ $\Sigma$ SFA ratio in breast muscles and adipose tissue, were more favourable for Garbonosa than for Rypińska flock (2.13 v/s 2.07 and 3.02 v/s 2.67, respectively). The higher content of unsaturated $n-6$ and $n-3$ fatty acids (except leg muscles) was found in lipids of muscles and adipose tissue of Garbonosa than Rypińska. The $\Sigma n-6 / \Sigma n-3$ ratio in the present study, in both analysed flocks of geese, was high and evidently exceeded the recommended values (Table 3). Slightly lower values of $\Sigma n-6 / \Sigma n-3$ ratio characterised lipids extracted from breast and leg of Rypińska muscles (8.65 and 8.59 respectively) compared to Garbonosa ( 9.08 and 8.60, respectively). Even higher values of $\Sigma n-6 / \Sigma n-3$ ratio, compared to lipid muscles, were stated in adipose tissue lipids and amounted 12.94 (Rypińska) and 13.42 (Garbonosa).

Table 3

Selected fatty acids composition (\% of the total fatty acids) in breast muscles, leg muscles and adipose tissue of goose breeds

\begin{tabular}{|c|c|c|c|c|c|c|}
\hline \multirow[t]{4}{*}{ Fatty acids, $\%$} & \multicolumn{6}{|c|}{ Flock of geese } \\
\hline & \multicolumn{2}{|c|}{ Rypińska } & \multicolumn{2}{|c|}{ Garbonosa } & \multirow{2}{*}{\multicolumn{2}{|c|}{$\begin{array}{l}\text { Rypińska Garbonosa } \\
\text { Adipose tissue, } n=20\end{array}$}} \\
\hline & \multirow{2}{*}{$\begin{array}{c}\text { Breast, } n=20 \\
\bar{x} \pm s\end{array}$} & \multirow{2}{*}{$\begin{array}{c}\text { Leg, } n=20 \\
\bar{x} \pm s\end{array}$} & \multirow{2}{*}{$\begin{array}{c}\text { Breast, } n=20 \\
\bar{x} \pm s\end{array}$} & \multirow{2}{*}{$\begin{array}{c}\text { Leg, } n=20 \\
\bar{x} \pm s\end{array}$} & & \\
\hline & & & & & $\overline{\mathrm{x}} \pm \mathrm{s}$ & $\overline{\mathrm{X}} \pm \mathrm{s}$ \\
\hline \multicolumn{7}{|c|}{ Saturated fatty acids (SFAs) } \\
\hline C 14:0 & $0.54^{B^{*}} \pm 0.07$ & $0.53^{A} \pm 0.03$ & $0.63^{A^{* * *}} \pm 0.08$ & $0.50^{B} \pm 0.02$ & $0.82^{A} \pm 0.02$ & $0.70^{B} \pm 0.01$ \\
\hline C 16:0 & $24.17^{* *} \pm 1.21$ & $23.02 \pm 1.12$ & $23.78^{* *} \pm 0.41$ & $22.54 \pm 0.99$ & $22.50^{A} \pm 0.06$ & $20.75^{\mathrm{B}} \pm 0.08$ \\
\hline C 18:0 & $7.31 \pm 0.50$ & $8.01 \pm 0.51$ & $6.94 \pm 0.30$ & $8.29^{* *} \pm 0.40$ & $3.92 \pm 0.22$ & $3.88 \pm 0.12$ \\
\hline$\Sigma$ SFA & 32.02 & 31.56 & 31.35 & 31.33 & 27.24 & 25.33 \\
\hline \multicolumn{7}{|c|}{ Unsaturated fatty acids (MUFAs) } \\
\hline C 16:1 cis-9 & $3.32^{\mathrm{B}} \pm 0.34$ & $3.68 \pm 0.23$ & $3.90^{A} \pm 0.22$ & $3.75 \pm 0.21$ & $4.01^{A} \pm 0.04$ & $3.23^{B} \pm 0.04$ \\
\hline C $16: 1$ trans -9 & $0.92^{b^{* *}} \pm 0.02$ & $0.78 \pm 0.02$ & $0.99^{a^{* * *}} \pm 0.02$ & $0.74 \pm 0.02$ & $0.82 \pm 0.01$ & $0.85 \pm 0.02$ \\
\hline C 18:1 cis-9 & $37.21^{\mathrm{a}} \pm 1.07$ & $37.64^{\mathrm{a}} \pm 0.75$ & $36.12^{\mathrm{b}} \pm 1.21$ & $37.33^{b} \pm 0.78$ & $49.98^{\mathrm{B}} \pm 0.17$ & $52.78^{A} \pm 0.20$ \\
\hline C $18: 1$ trans -11 & $0.42 \pm 0.08$ & $0.38^{\mathrm{a}} \pm 0.02$ & $0.37^{*} \pm 0.03$ & $0.29^{b} \pm 0.20$ & $0.41^{\mathrm{b}} \pm 0.018$ & $0.44^{\mathrm{a}} \pm 0.10$ \\
\hline$\Sigma$ MUFA & 41.87 & 42.48 & 41.40 & 42.11 & 55.22 & 57.29 \\
\hline \multicolumn{7}{|c|}{ Polyunsaturated fatty acids (PUFAs) } \\
\hline C $18: 2 n-6$ & $14.76^{B} \pm 1.06$ & $16.26^{*} \pm 0.89$ & $15.87 \mathrm{~A}^{* *} \pm 1.01$ & $15.97 \pm 0.21$ & $16.09^{B} \pm 0.04$ & $17.57^{A} \pm 0.08$ \\
\hline a C18:3n-3 & $1.04^{* *} \pm 0.01$ & $0.83 \pm 0.02$ & $1.00^{* *} \pm 0.02$ & $0.80 \pm 0.02$ & $1.26 \pm 0.04$ & $1.34 \pm 0.03$ \\
\hline C 20:4n-6 & $6.36^{B} \pm 0.34$ & $7.63^{* *} \pm 032$ & $6.96^{A} \pm 0.18$ & $7.79^{* *} \pm 0.10$ & $0.22^{\mathrm{B}} \pm 0.02$ & $0.41^{A} \pm 0.02$ \\
\hline C 20:5 n-3 EPA & $1.10 \pm 0.02$ & $1.49^{* *} \pm 0.05$ & $1.16 \pm 0.02$ & $1.51^{* *} \pm 0.06$ & ----- & ----- \\
\hline C 22:4 n-6 & $0.64 \pm 0.03$ & $0.75^{* *} \pm 0.02$ & $0.69 \pm 0.03$ & $0.76^{* *} \pm 0.03$ & ----- & ----- \\
\hline C 22:6n-3 DHA & $0.38^{B} \pm 0.02$ & $0.54 \mathrm{~A}^{* *} \pm 0.03$ & $0.44^{\mathrm{A}} \pm 0.02$ & $0.54^{B^{* * *}} \pm 0.04$ & ----- & ----- \\
\hline$\Sigma$ PUFAs & 24.28 & 27.50 & 26.11 & 27.38 & 17.57 & 19.32 \\
\hline$\Sigma$ UFAs & 66.15 & 69.98 & 67.21 & 69.41 & 72.79 & 76.61 \\
\hline$\Sigma$ UFA/ $\Sigma$ SFA ratio & 2.07 & 2.22 & 2.13 & 2.22 & 2.67 & 3.02 \\
\hline$\sum n-6$ & 21.79 & 24.64 & 23.52 & 24.52 & 16.31 & 17.98 \\
\hline$\sum n-3$ & 2.52 & 2.87 & 2.59 & 2.85 & 1.26 & 1.34 \\
\hline$\sum n-6 / \Sigma n-3$ ratio & 8.65 & 8.59 & 9.08 & 8.60 & 12.94 & 13.42 \\
\hline Total fat, $\%$ & $3.32^{b} \pm 0.04$ & $3.56^{\mathrm{B}} \pm 0.05$ & $3.41^{\mathrm{a}} \pm 0.08$ & $3.69^{A^{*}} \pm 0.99$ & $98.2 \pm 1.22$ & $98.7 \pm 1.34$ \\
\hline
\end{tabular}

${ }_{\mathrm{a}, \mathrm{b}} P \leq 0.05,{ }^{A}, \mathrm{~B} P \leq 0.01$, statistically significant differences in lines between mean values in relation to flocks regarding the same type of muscles and abdominal fat (estimated separately), ${ }^{*} P \leq 0.05$, ${ }^{* *} P \leq 0.01$, statistically significant differences in lines between mean values in relation to type of muscles estimated within individual flocks 


\section{Discussion}

The unsaturated fatty acids were predominant in the total fatty acids composition of breast and leg muscles and the adipose tissue of both geese breeds. The major fatty acids were: C 18:1 cis-9, C 18:2 n-6 and C 20:4 n-6. The content of fatty acids, therein the long-chain PUFAs, in lipids of individual type muscles (breast and leg) from both geese flocks was different in spite of the same environmental conditions and feeding. Higher amounts of C 20:4 n-6 and C 20:5 n-3 fatty acids in Garbonosa muscles (breast and leg) than in Rypińska muscles may be associated with breed-specifically higher expression or activity levels of delta-5 and delta- 6 desaturate in Garbonosa breast and leg muscles. The concentrations of C 18:2 n-3 and C 20:4 $n-6$ fatty acids of the investigated geese breast and leg muscles and adipose tissue were higher and the $C$ 18:1 cis-9 content lower than the data obtained previously by Gumułka et al. (2006) for 17-week-old Zatorska and White Kołuda. The C 18:0 content in breast and leg muscles as well as adipose tissue for both analysed flocks was lower than those reported by the above-mentioned authors (7.31\% - Rypińska and 6.94\% - Garbonosa vs. 9.68\% Zatorska and 9.75\% - White Kołuda; $8.01 \%$ - Rypińska and 8.29\% - Garbonosa vs. $8.83 \%$ - Zatorska and 8.74\% - White Kołuda as well as 3.92\% - Rypińska and 3.88\% - Garbonosa vs. $5.61 \%$ - Zatorska and $6.60 \%$ - White Kołuda, respectively); however C 16:0 was generally similar. The similar studies on Turkish native breeds of geese have been carried out by Arslan et al. (2004). These authors showed lower concentration of C 14:0 (0.44\%), C 16:1 cis9 (2.30\%), C 18:2 n-6 (11.77\%) and a C 18:3 n-6 (0.54\%) and higher concentration of C 18:0 (7.39\%) and C 18:1 cis-9 (52.99\%) fatty acids in lipids of, adipose tissue, from the 85-day-old Turkish native ganders similarly fed, compared to the present results. However Rosiński et al. (1999), who analysed fatty acids profile of adipose tissue lipids from 17-week-old females of White Kołuda geese (W 11 and W 33 strains as well as interbred hybrids W 13 and W 31), stated higher concentration of $C 16: 0$ content (by $1.82 \%$ ) and lower level of the UFAs and PUFAs (except C 18:1 cis-9) compared to the results of research presented in the paper. The results of the present study, concerning the saturated fatty acids contents - especially $C$ 16:0 - in breast muscle lipids, were lower than those reported by Salichon et al. (1997) and Wołoszyn et al. (2006), who analysed fatty acids profile in breast muscle lipids from Muscovy and Pekin type (P 33 and A3) population ducks, respectively. The long-chain polyunsaturated fatty acids in geese adipose tissue are notable in their apparent absence, although this may be simply a reflection, as it was suggested by Leskanich \& Noble (1997), of their absence in the respective diets rather than due to the type of species. Furthermore the absence of $C 20: 5$ $n-3$, C 22:4 n-6 and C 22: $n-3$ in abdominal adipose tissue may indicate negligible expression of delta- 5 desaturate, delta- 6 deasturate and elongate in this tissue type. The data referring to the MUFAs and the PUFAs contents in Rypińska and Garbonosa muscles were higher than the data previously published by Ratnayake et al. (1989) - by $8.84 \%$ and $7.03 \%$, respectively for raw meat from geese (without skin) fed with standard diet and Łukaszewicz \& Kowalczyk (2008) - by $1.66 \%$ and $4.98 \%$ respectively for breast muscles from White Kołuda male and female geese. The UFA/SFA ratio in breast muscles and adipose tissue lipids was higher in Garbonosa compared to the Rypińska flock. The UFA/SFA ratio was slightly more favourable for the breast and leg muscles and adipose tissue in comparison to the results obtained by Gumułka et al. (2006) for Zatorska - except abdominal fat - and White Kołuda - W 31 geese. From nutritional and physiological points of view it is very important to keep the right ratio 
between $n-6$ and $n-3$ groups of polyunsaturated fatty acids. Generally, the consumption of $n-3$, but not $n-6$ PUFAs has been advised (Leskanich \& Noble 1997). According to previous results the recommended ratio of $n-6$ to $n-3$ PUFAs intake should amount from 4:1 (Aldai et al. 2007 up to 5:1 - 6:1 (Leskanich \& Noble 1997). In the present study, the PUFA $n-6 / n-3$ ratio in lipids ranged from 8.59 - Rypińska (leg muscle) to 9.08 - Garbonosa (breast muscle) lipids and from 12.94 (Rypińska) up to 13.42 (Garbonosa) in adipose tissue lipids and they were higher than the recommended value of human diets by the above mentioned authors. In spite of ducks' meat the $n-6 / n-3$ PUFA ratio was evidently lover and amounted for K2 (Miniducks) and SB (cross-breeds of ducks from three conservative groups A1, A2 and A3) than obtained for investigated breeds of geese -5.84 and 4.17, respectively (Wołoszyn et al. 2011). Similar value of $n-6 / n-3$ PUFA ratio to the stated in the present study was obtained by Has-Schön et al. (2008) for breast muscle from the 19th week of age turkeys of Nicholas 700 breed $(n-6 / n-3=8.05)$, fed feed with added $\approx 3.0 \%$ of the total meal weight commercial preparation Bergafat (Berg+Schmidt GmbH \& Co. KG, Hamburg, Germany) (30-44\% of saturated fatty acids, $35-45 \%$ monounsaturated fatty acids and less than $4 \%$ of arachidonic acid (C 20:0) as well as other fatty acids with 20 or more carbon atoms).

Even though, the $n-6 / n-3$ PUFA ratio in lipids of analysed muscles and adipose tissue was higher from the recommended values, it was at the same time evidently lower than in the typical western diet which, as reported by Simopoulos (2003), amounted to approximately 20:1. Therefore one can state, that $n-6 / n-3$ PUFA in muscles and adipose tissue lipids is only a reasonable compromise between the current mean value in developed countries and the above-mentioned optimum. Generally one can state, that the lipids content in the investigated muscles as well as adipose tissue depended on geese breeds. Furthermore lipids of breast and leg muscles as well as adipose tissue in both analysed breeds of geese characterised by a high proportion of the polyunsaturated fatty acids, therein long-chain PUFAs, what also in the light of previous research (Wężyk et al. 2003, Arslan et al. 2004) is beneficial regarding consumers' health.

\section{References}

Aldai N, Murray BE, Oliván M, Martínez A, Troy DJ, Osoro K, Nájera Al (2007) The influence of breed and mhgenotype on carcass conformation meat physic-chemical characteristics, and the fatty acid profile on muscle from yearling bulls. Meat Sci 72, 486-495

AOAC (1990) Official Methods of Analysis, 15th ed. Association Analytical Chemist. Washington DC, USA

AOCS (1997) Official Methods and Recommended Practices of the American Oil Chemist's Society, 2nd ed., American Oil Chemist's Society, AOACS Press, Champaign, Illinois, USA, 1-2

Arslan C, Citil M, Saatci M (2004) Effects of L-Carnitine administration on growth performance, carcass traits, serum lipids and abdominal fatty acid compositions of geese. Revue Méd Vét 155, 315-320

EFSA (2010) Scientific opinion on dietary reference values for fats, including saturated fatty acids, polyunsaturated fatty acids, monounsaturated fatty acids, trans fatty acids, and cholesterol. EFSA Journal 8 (1461), 1-107

Falconer DS, Mackay TFC (1996) Introduction to Quantitative Genetics. 4th ed. Harlow/Essex, Longman Group Ltd., England, 25-34

FAO (2000) World Watch List for Domestic Animal Diversity, 3rd ed., Rome, Italy, 351

Folch J, Less M, Sloane Stanley GH (1956) A simple method for the isolation and purification of total lipids from animal tissues. J Biol Chem 226, 497-509 
Gumułka M, Kapkowska E, Borowiec F, Rabsztyn A, Połtowicz K (2006) Fatty acid profile and chemical composition of muscles and abdominal fat in geese from genetic reserve and commercial flock. Anim Sci 1 (Suppl.), 90-91

Has-Schön E, Škrtić Z, Kralik G (2008) Beneficial effects of different dietary oils on cholesterol level and fatty acids profile of turkey pectoral muscle. Ital J Anim Sci 7, 161-171

Książkiewicz JM (2003) Comparison of reproduction and carcass traits in light type of ducks of four conservative flocks over eight generations. Arch Tierz 46, 377-389

Leskanich CO, Noble RC (1997) Manipulation of the $n-3$ polyunsaturated fatty acid composition of avian eggs and meat. World Poult Sci J 53, 155-183

Łukaszewicz E, Kowalczyk A (2008) Effect of supplementation with organic selenium and vitamin E on fatty acid composition in commercial White Kołuda geese meat. Proc. 23rd World Poult Congr, Brisbane, Australia (Mat. on CD)

McAfee AJ, McSorley EM, Cuskelly GJ, Moss BW, Wallace JMW, Bonham MP, Fearon AM (2010) Red meat consumption: An overview of the risks and benefits. Meat Sci 84, 1-13

Mazanowski A (2002) [Reserve and conservative flocks of geese]. Wyd IZ Kraków B-4, 8-11 [in Polish]

Mennicken L, Ponsuksili S, Tholen E, Thi Kim Khang N, Streier K, Petersen J, Schhellander K, Wimmers K (2005) Divergent selection for $\omega-3: \omega-6$ polyunsaturated fatty acids ratio in quail eggs. Arch Tierz 48, 527-534

Minister of Agriculture and Rural Development (2004) Dz. U. Nr. 63, item No. 589. 24 March 2004. [Directive concerning additional information placed on labels of animal feedstuff] [in Polish]

Qi KK, Chen JL, Zhao GP, Zheng MQ, Wen J (2010) Effect of dietary omega6/omega3 on growth performance, carcass traits, meat quality and fatty acid profiles of Beijing-you chicken. J Anim Physiol Anim Nutr (Berl) 94, 474-485

Ratnayake WMN, Ackman RG, Hulan HW (1989) Effect of redfish meal enriched diets on the taste and $n-3$ PUFA of 42-day old broiler chickens. J Sci Food Agricult 49, 59-74

Rosiński A (2000) [The analysis of direct and correlated selection effects in two goose strains]. PhD Thesis. Agricultural University Poznań, Poland, 107 [in Polish]

Rosiński A, Skrabka-Błotnicka T, Wołoszyn J, Przysiężna E, Eliminowska-Wenda G (1999) [Effect of genotype and sex on abdominal fat quality in White Kołuda geese]. Rocz Nauk Zoot 26, $89-98$ [in Polish]

Salichon RM, Baéza E, Leclercq B (1997) Biochemical characteristics of Muscowy duck breast. Sci des Aliments $17,227-233$

Simopoulos AP (2003) Importance of the ratio of omega-6/omega-3 essential fatty acids: evoluationary aspects. World Rev Nutr Diet 92, 1-22

StatSoft Inc. (2009) Statistica (data analysis software system), version 9.0. (www.statsoft.com)

Wężyk S, Rosiński A, Bielańska H, Bacowski H, Cywa-Benko J (2003) A note on the meat quality of W 11 and W 33 White Kołuda geese strains. Anim Sci Pap Rep 21, 191-199

Wołoszyn J, Okruszek A, Orkusz A, Wereńska M, Książkiewicz J, Grajeta H (2011) Effect of duck genotype on leg muscle properties. Arch Tierz 54, 649-660

Received 30 June 2011, accepted 7 February 2012.

Corresponding author:

Andrzej Okruszek

email: andrzej.okruszek@ue.wroc.pl

Department of Animal Food Technology, Wroclaw University of Economics, Komandorska 118/120, 53-345 Wrocław, Poland 